\title{
Usage of Lactobacillus rhamnosus as a Probiotic in Sea Bass (Dicentrarchus labrax ${ }^{[*]}$
}

\author{
Fatma ÖZTÜRK $^{1 *} \quad$ Ömer Memduh ESENDAL ${ }^{2}$ \\ ${ }^{I}$ Department of Fish Processing Technology, Faculty of Fisheries, Izmir Katip Celebi University, Izmir, Turkey. \\ ${ }^{2}$ Department of Microbiology Faculty of Veterinary Medicine, Near East University, Nicosia, TRNC.
}

How to cite: Öztürk, F. \& Esendal, Ö.M. (2020). Usage of Lactobacillus rhamnosus as a probiotic in Sea bass (Dicentrarchus labrax). J. Anatolian Env. and Anim. Sciences, 5(1), 93-99.

Atıf yapmak için: Öztürk, F. \& Esendal, Ö.M. (2020). Levrek balıklarında (Dicentrarchus labrax) probiyotik olarak Lactobacillus rhamnosus kullanımı. Anadolu Çev. ve Hay. Dergisi, 5(1), 93-99.

: https://orcid.org/0000-0003-4763-3801 iD: https://orcid.org/0000-0002-2700-2634

\begin{abstract}
In this study, the effects of Lactobacillus rhamnosus (ATCC 53103) used as a probiotic supplement on the deformation rate, survival rate, weight gain, and intestinal microflora in sea bass (Dicentrarchus labrax) were investigated. For this purpose, the probiotic agent was incorporated into the rearing water and Artemia nauplii culture at concentrations of $10^{6} \mathrm{CFU} / \mathrm{mL}$ and $10^{8} \mathrm{CFU} / \mathrm{mL}$, respectively. The incorporation of the probiotic was carried out until the $50^{\text {th }}$ day. From 50 to 125 days post-hatching, $10^{9} \mathrm{CFU} / \mathrm{g}$ of probiotic was incorporated into the diet of the both groups every day. The deformation rates of the larvae were recorded as $5 \%$ in the group received the probiotic via rearing water, $2 \%$ in the group received the probiotic via Artemia culture, and $7 \%$ in the control group $(\mathrm{P}<0.01)$. Survival rates of the experimental groups received probiotics were found significantly higher than the control group $(\mathrm{P}<0.01)$. No significant differences were found on the weight gain of sea bass individuals received probiotic $(\mathrm{P}>0.01)$. On the other hand, It was found that the probiotic addition to Artemia culture leads to a decrease in the number of Vibrio spp., $(\mathrm{P}<0.01)$. As a result, it has been determined that the addition of probiotics to rearing water and especially Artemia culture has positive effects on the rate of larval survival and deformation.
\end{abstract}

Keywords: Deformation, fish, microflora, probiotic, survival rate.

\section{Levrek Balıklarında (Dicentrarchus labrax) Probiyotik Olarak Lactobacillus rhamnosus Kullanımı}

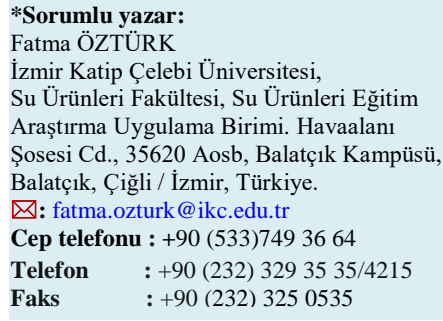

Öz: Bu çalışmada, levrek balıklarında (Dicentrarchus labrax) probiyotik olarak kullanılan Lactobacillus rhamnosus (ATCC 53103)'un balıkların deformasyon oranı, yaşama oranı, ağırlık artışı ve bağırsak mikroflorası üzerine etkisi araştırılmıştır. Bu amaçla, probiyotik ilavesi yetiştirme suyuna $10^{6} \mathrm{kob} / \mathrm{mL}$ ve Artemia nauplii kültürüne $10^{8} \mathrm{kob} / \mathrm{mL}$ düzeyinde yapılmış ve 50. güne kadar devam etmiştir. 50. günden sonra 125. güne kadar her gün, bu gruplardaki balıkların toz yemine $10^{9} \mathrm{kob} / \mathrm{g}$ düzeyinde probiyotik ilavesine devam edilmiştir. Deneme sonunda larvalardaki deformasyon oranları; yetiştirme suyuna probiyotik ilave edilen grupta $\% 5$, Artemia kültürüne ilave edilen grupta $\% 2$ ve kontrol grubunda $\% 7$ olarak tespit edilmiştir $(\mathrm{P}<0.01)$. Probiyotik ilave edilen deneme gruplarının yaşama oranı kontrol grubuna kıyasla önemli düzeyde yüksek bulunmuştur $(\mathrm{P}<0.01)$. Probiyotik ilavesinin balıkların ağırlık artışı üzerinde önemli bir etkisinin olmadığ probiyotik ilavesinin Vibrio spp. sayısında önemli düzeyde azalmaya neden olduğu belirlenmiştir $(\mathrm{P}<0.01)$. Sonuç olarak yetiştime suyuna ve özellikle Artemia kültürüne probiyotik ilavesinin larval yaşama oranı ve deformasyon oranı üzerinde olumlu etki gösterdiği tespit edilmiştir.

Anahtar kelimeler: Balık, deformasyon, mikroflora, probiyotik, yașama oranı.

\footnotetext{
${ }^{[*]}$ Produced from PhD thesis titled "The effect of using Lactobacillus rhamnosus as a probiotic on the performance of sea bass (Dicentrarchus labrax)".
} 


\section{INTRODUCTION}

In parallel with the worldwide expansion of aquaculture, there has been a dramatic increase in microbial fish diseases. Several pathogenic and opportunistic bacteria have caused high mortality rates during larval first-feeding (Franke et al., 2017). Therefore, a wide variety of antibiotics have been used in order to prevent bacterial diseases in industrial animals (Gobi et al., 2018). However, using large amounts of antibiotics in farm animals have resulted in antibiotic residues in tissues, an imbalance of normal intestinal flora, a reduction in beneficial microbial populations in the intestines, and the generation of antibiotic-resistant bacteria (Byun et al., 1997; Lin et al., 2017; Marti et al., 2018; Preena et al., 2019). Consequently, alternative methods are required to support digestive system and immune system of fish larvae. Among these, one of the methods which has gained acceptance in the aquaculture industry is to control potential pathogens through the use of probiotic bacteria (Harzevili et al., 1998; Nikoskelainen et al., 2003; Arıg et al., 2013; Gumus et al., 2016; Goda et al., 2018).

Probiotics are defined as a viable pure or mixed culture of microorganisms which provides benefits to the host (Van Doan et al., 2018; Çelik et al., 2019). They prevent colonization of pathogenic microorganisms to the intestinal epithelial cells and avoid their propagation by producing antimicrobial metabolites. They also improve the properties of the indigenous microflora and thus improve the health status of the host and increase feed conversion (Byun et al., 1997; Nguyen et al., 2017). In aquaculture, probiotics are used to increase production, improve water quality, decrease the use of antibiotics and other chemicals, and increase resistance to diseases (Van Doan et al., 2018). They are added to the water and administered to artificial feeds and live foods, such as artemia and rotifer (Sutthi et al., 2018). The most widely used bacteria as probiotics are lactic acid bacteria (LAB) (Silvi et al., 2008; Lamari et al., 2013; Piccolo et al., 2015; Didinen et al., 2016; Ljubobratovic et al., 2017). The normal microflora of the gastrointestinal tract of healthy fish includes LAB. LAB inhibits the growth of various pathogens by producing substances like organic acids and bacteriocins (Byun et al., 1997; Jöborn et al., 1997).

In this study Lactobacillus rhamnosus (ATCC 53103) was added to the rearing water, live food cultures and artificial feeds of sea bass in order to study its effects on the deformation rate, survival rate, weight gain and intestinal microbial flora.

\section{MATERIAL AND METHOD}

Probiotic Strain and Their Preparation: In this study, L. rhamnosus ATCC 53103 strain which was obtained from a LGC Promochem Ltd. (Teddington, UK) was used as probiotic. In order to produce probiotics that would be used in the experiments, $200 \mathrm{~mL}$ Man, Rogosa and Sharpe Agar (MRS, Merck) was put into roux bottles and sterilized at $118^{\circ} \mathrm{C}$ for $15 \mathrm{~min}$. in autoclave (Nüve, OT 90L). Then, the medium was hardened in roux bottles placed in a horizontal position. One $\mathrm{mL}$ of activated culture was aseptically transferred into a roux bottle, and incubated at $37^{\circ} \mathrm{C}$ for $18-24$ hours. After the total number of bacteria was determined in the stock probiotic culture, required concentrations to be used in experimental groups were prepared by sterile physiological saline solution. The bacterial suspensions were kept at $4{ }^{\circ} \mathrm{C}$ until used within one week.

Experimental Design: In this research, it was carried out in the Hatko Sea Products Inc., Ören hatchery, Milas, Muğla, Turkey in 2005. Ethics committee approval was not required for fish at the time of the study.

Sea bass (Dicentrarchus labrax) larvae, average weight $0.21 \pm 0.01 \mathrm{mg}$, were taken in commercial marine hatcheries. The larvae were immediately transferred to the larvae tanks and trials were started. The probiotic bacteria was administered to sea bass for 125 days. The experiment was carried out in three groups; Following the hatching, the larvae were stocked in cylinders-conical tanks $\left(2 \mathrm{~m}^{3}\right)$, with initial stocking density of 125 larvae /L.

Group 1: L. rhamnosus ATCC 53103 was added to the rearing water and diet. Taking the volume of the water in the rearing tanks into consideration, $10^{12} \mathrm{CFU} / \mathrm{mL}$ L. rhamnosus ATCC 53103 strain was added to the rearing water from 9 to 50 days post-hatching (DAH). In this way, the final concentration of bacteria in the tank became $10^{6}$ $\mathrm{CFU} / \mathrm{mL}$ during $50 \mathrm{DAH}$. Probiotics were added to the tanks twice a day at 08:00 and 16:00 hours, prior to Artemia nauplii addition. From 50 to $125 \mathrm{DAH}$, the fishes were given diet containing $10^{9} \mathrm{CFU} / \mathrm{g}$ L. rhamnosus ATCC 53103. Probiotic was sprayed on fish diet and mixed by hand.

Group 2: L. rhamnosus ATCC 53103 was supplied to larvae via Artemia nauplii and added to the diet. From 9 to 50 DAH, larvae were fed with Artemia nauplii to which $10^{8} \mathrm{CFU} / \mathrm{mL}$ L. rhamnosus ATCC 53103 strain was added. After the $50 \mathrm{DAH}$, the bacterial administration was performed with diet. From 50 to $125 \mathrm{DAH}$, the fishes were given diet containing $10^{9} \mathrm{CFU} / \mathrm{g}$ L. rhamnosus ATCC 53103. Probiotic was sprayed on fish diet and mixed by hand.

Control group: L. rhamnosus ATCC 53103 was not supplied to larvae. Between 9 and 50 DAH, larvae were fed with Artemia nauplii. From 50 to $125 \mathrm{DAH}$, the fishes were fed with microparticle diet $(300 \mu-1.2 \mathrm{~mm})$. Daily feeding rate was about $3.5 \%$ of total body weight. 


\section{Determination of Intestinal Microflora of the} Fish and Bacterial Load in Artemia Culture: After hatching, fish samples were taken on days 20,27, 50, 58, 86, 104 and 121 and microbiological analyzes were done. In order to determine intestinal flora of the fish, during the larval period, about 20 larvae and 5-10 juveniles were put into sterile tubes (Muroga et al., 1987; Grisez et al., 1997). They were immersed in $0.1 \%$ benzalkonium chloride saline solution for $1 \mathrm{~min}$; then, they were washed under sterile distilled water for $30 \mathrm{~s}$. After that, these fish samples were homogenized using saline solution. Artemia nauplii used in feeding the fish larvae were taken $1 \mathrm{~g}$ and were homogenized in $9 \mathrm{~mL}$ saline solution (Muroga et al., 1987; Rollo et al., 2006). Homogenates were serially diluted and $0.1 \mathrm{~mL}$ of appropriate dilutions was spread onto plates. Man, Rogosa and Sharpe (MRS) Agar was used for lactic acid bacteria (LAB) and incubated anaerobically at $30^{\circ} \mathrm{C}$ for 48 hours, Violet Red Bile Agar (VRBA, Merck) was used for total enterobacteria (TEB) and incubated at $37^{\circ} \mathrm{C}$ for 24 hours, Plate Count Agar (PCA, Merck) was used for total aerobic mesophilic bacteria (TAMB) and incubated at $30^{\circ} \mathrm{C}$ for 48 hours, Blood Agar (BA, Merck) was used for total anaerobic bacteria (TAB) and incubated at $30^{\circ} \mathrm{C}$ for 24 hours in a steel jar, Thiosulfate-Citrate-Bile-Sucrose Agar (TCBSA, Merck) was used for Vibrio spp. and incubated at $30^{\circ} \mathrm{C}$ for 24 hours (Harrigan, 1998, Nikoskelainen et al., 2001; Villamil et al., 2010; Hamza et al., 2016).

Determination of Survival Rate, Deformation Rate, and Weight Gain: At the end of the experiment, survival rate of larvae was determined by counting the larvae remaining in the tanks. For determining the rate of deformation, at the end of the rearing period in the hatchery, the deformed larvae were separated from the healthy individuals. In order to do this, larvae were anesthetized with phenoxyethanol (200 ppm) (Crespel et al., 2017). Immobile larvae were placed on an illuminated glass table. The individuals who had spine, mouth, fin, and gill deformations were separated. Larvae weight was measured using the electronic balance $(0,0001 \mathrm{~g}$; Shimadzu ATX-224, Japan) at the beginning and end of the experiment. The weight gain of fish was calculated by following formula; Weight gain $(\mathrm{g} / \mathrm{fish})=$ Final weight initial weight.

Statistical Analysis: Statistical analysis was carried out with SPSS 11.5 (Chicago, USA). The obtained data about intestinal flora and weight gain were analyzed using ANOVA (analysis of variance). The results were evaluated by Duncan Multiple Comparison Test. Chisquare analysis was used to compare the groups in terms of survival and deformation rates. Differences among treatments were considered significant at the $\mathrm{P}<0.01$ level. All measurements were carried out in duplicate.

\section{RESULTS AND DISCUSSION}

Intestinal Microflora: In the inoculations made until the $50^{\text {th }}$ day, the number of TAMB were not different between Group 1 and Group 2, but later their numbers substantially decreased in Group $2(\mathrm{P}<0.01)$. Between 20 and 58 days, it was found that the number of TEB were higher both in Groups 1 and 2, than the control group during the experiment period $(\mathrm{P}<0.01)$. The number of Vibrio spp. were lower in the experimental groups, to which probiotics were added, than the control group. The lowest number Vibrio spp. was detected in the fish in Group $2(\mathrm{P}<0.01)$ (Figure 1a, 1b, 1c, 1d).

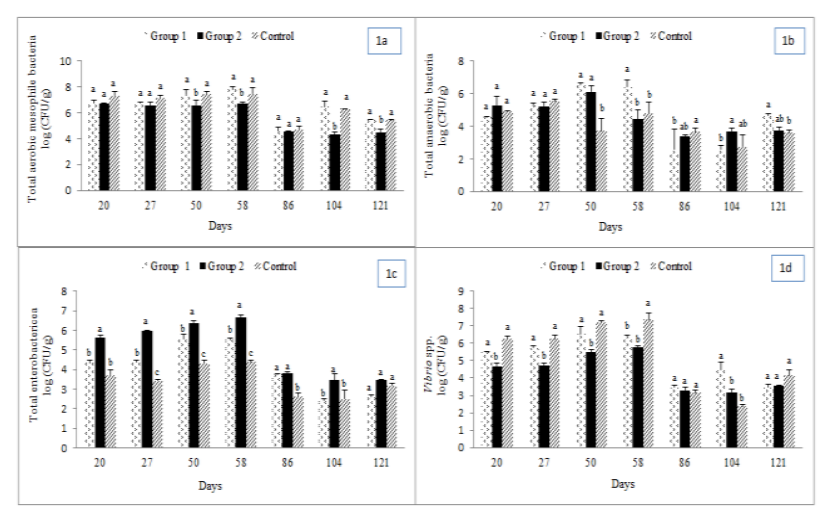

Figure 1. Changes in the number of TAMB (a), TAB (b), Enterobacteriaceae (c), and Vibrio spp. (d) in the intestinal flora of the sea bass.

In this research, after the larvae in the experimental groups started to receive feed, the number of Enterobacteriaceae in their intestines increased, while the number of Vibrio spp. decreased. The situation was just the opposite in the control group. When experimental groups are compared, the number of TEB in Group 2 was higher than Group 1. The number of Vibrio spp. was lower. The tendency of a decline in the number of Vibrio spp. indicates that they are inhibited by the probiotic bacteria. It was observed that more successful results would be obtained by adding probiotic bacteria to Artemia culture. These results were similar to many studies. For instance, in the research conducted by Byun et al., (1997), it was determined that the number of aerobic and anaerobic bacteria in the intestinal flora of flounders decreased by using Lactobacillus spp. whereas the number of Enterobacteriaceae increased. Gatesoupe, (1991) showed that in rotifer culture, the use of Lactobacillus plantarum decreased the number of aerobic bacteria. Rollo et al., (2006) that the use of Lactobacillus fructivorans and $L$. plantarum in artemia and rotifer cultures decreased the number of aerobic and anaerobic bacteria as well as Enterobacteriaceae and Staphylococcus spp. in sea bream. Hamza et al., (2006) reported that the number of total bacteria in the digestive system of sea bass applied 
probiotic (Virgibacillus proomii and Bacillus mojavensis) decreased significantly. In contrast, Jöborn et al., (1997), stated that when Carnobacterium spp. was used as a probiotic, total number of aerobic bacteria increased in the intestinal flora of rainbow trout. Similarly, Silvi et al., (2008) also reported that Lactobacillus delbrueckii subsp delbrueckii strain on the intestinal microbiota of sea bass was effective. It has been stated that total intestinal microbiota dramatically increases except for day 22, in particular the number of Enterobacteriaceae is affected by probiotic therapy.

In this study, the number of Vibrio spp. in the intestines of the fish in Group 1 and Group 2 was found to be lower than the control group. The lowest number of bacteria was observed in Group 2. Not all of the probiotic bacteria added to rearing water could be taken by the fish; however, the bacteria added to Artemia culture was filtered by Artemia and more bacteria could be taken by the fish. As determined in the study conducted by Reitan et al., (1993), it is estimated that the reason of a decrease in the number of Vibrio spp. is that probiotic bacteria are bioencapsulated by live feed organisms. Also, Villamil et al., (2010) reported that Pediococcus acidilactici transmitted via live feed inhibited Vibrio splendidus in turbot larvae. Goda et al., (2018) reported that the Bactozyme, a commercial product containing probiotic, cause decrease the number of Vibrio spp. in the intestinal flora of the sea bass. In conclusion, in this study, it was determined that the use of L. rhamnosus, especially in Artemia culture, prevented the colonization and proliferation of some opportunistic pathogens.

The Number of Bacteria in Artemia Culture: It was found that in the inoculations made from Artemia nauplii, the number of Vibrio spp. was $7.01 \pm 0.55$, TEB was $4.56 \pm 0.82 \log \mathrm{CFU} / \mathrm{g}$, and TAMB was $8.00 \pm 0.43 \mathrm{log}$ $\mathrm{CFU} / \mathrm{g}$. After the Artemia culture was incubated with probiotic bacteria for 2 hours, $10^{2} \mathrm{CFU} / \mathrm{g}$ lactic acid bacteria were detected in MRS Agar.

The larval form of most fish is released in an early ontogenetic phase. They start feeding although neither the digestive tract nor the immune system are still fully developed, therefore, these larvae are exposed to gastrointestinal microbiota-associated diseases (Silvi et al., 2008). During first feeding, the microorganisms found in feed and water goe to larval intestine. The first colonization in fish intestine is of great importance in terms of host health and development. For the formation of a balanced intestinal microflora, probiotic bacteria must be used soon after hatching (Hamza et al., 2016).

It is a well-known fact that in the formation of the fish intestinal flora, rearing water and the species of bacteria on the live feed are effective. Artemia is one of the best food sources for many species of animals which were cultured. However, Artemia nauplii have heavy bacterial loads and therefore they are considered as the most important vector which is responsible for carrying pathogenic bacteria into rearing systems (Reitan et al., 1993). In this research, the number of Vibrio spp. and TAMB were $7.01 \quad \log$ CFU/nauplii and $8.00 \quad \log$ CFU/nauplii, respectively. Hameed and Balasubramanian, (2000) stated that the number of TAMB was $3.8 \times 10^{3}$ $8.1 \times 10^{3} \mathrm{CFU} /$ nauplii and the number of Vibrio spp. was 9.4 $\times 10^{2}-4.3 \times 10^{3}$ CFU/nauplii. Olsen et al., (2000) also stated that total number of bacteria was $2.4 \times 10^{4}$ CFU/nauplii and that $58 \%$ of the total bacteria consisted of Vibrio spp. It is thought that this difference comes from the fact that Artemia is a biological product and they are obtained from different regions. In addition, during the study period in which Artemia was used, the numbers of bacteria found in the intestinal flora of the fish were higher than the period during which commercial diet was used. Therefore, it is concluded that the high bacterial load in the larvae resulted from Artemia culture.

Survival Rate, Deformation Rate, and Weight

Gain: At the end of the experiment, the survival rates of Group 1, Group 2, and the control group were determined as $27.4 \%, 34.8 \%$ and $18.9 \%$, respectively. The survival rates of the experimental groups that received probiotic bacteria were significantly higher than the control group $(\mathrm{P}<0.01)$ (Figure 2a). Deformation rates of the experimental groups are shown in Figure $2 b$. The differences between the experimental groups and the control group were regarded as significant $(\mathrm{P}<0.01)$. The average weights of the fish in experimental groups are shown in Figure 2c. In the $20^{\text {th }}$ day of experiment, the average weights of the experimental groups were $0.21 \pm 0.01 \mathrm{mg}$ while at the end of the experiment, the average weights of the Group 1, Group 2, and the control group were determined as $2.82 \pm 0.08 \mathrm{~g}, 2.83 \pm 0.03 \mathrm{~g}$, and $2.85 \pm 0.1 \mathrm{~g}$, respectively. The average weight gains were compared between experimental groups, and no significant differences were observed $(\mathrm{P}>0.01)$.

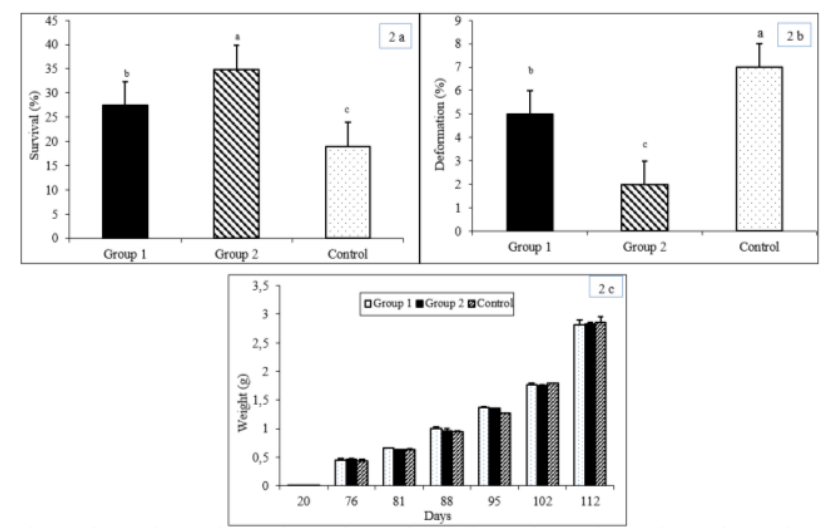

Figure 2. The survival, deformation rate, and weight of the sea bass larvae. 
In this study, the rate of larval survival in the experimental groups with probiotic bacteria was higher than the control group. The application of probiotics via Artemia gave better survival rates. Similar results were obtained by many researchers. For example, Silvi et al., (2008) and stated that the L. delbrueckii subsp. delbrueckii strain influenced the survival rate of sea bass. Piccolo et al., (2015) reported that the L. plantarum strain increased survival of sea bass. In the study carried out by Hamza et al., (2016) two separate probiotics (Virgibacillus proomii and Bacillus mojavensis) were mixed with the diet of sea bass, and the survival rate was found to be significantly higher.

Developmental conformation is a critical issue for fish hatcheries. The skeletal deformities develop during especially ontogenesis as far as metamorphosis (Lamari et al., 2013). In many studies it was stated that these deformities could be reduced by using probiotics (Lamari et al., 2013; Aubin et al., 2005; Lin et al., 2017). In this research, the deformation rate in larvae is $5 \%$ in Group 1, $2 \%$ in Group 2 and $7 \%$ in the Control Group. TovarRamirez et al., (2004) reported that the addition of Debaryomyces hansenii to the feed of sea bass larvae decreased deformation rates significantly. It has been reported that skeletal deformation significantly decreased in the pike-perch where Lactobacillus strains were used (Ljubobratovic et al., 2017). Lamari et al., (2013) investigated the effects of lactic acid bacteria on the histological development of the sea bass and indicated that the spine deformities had the highest incidence in the Lactobacillus casei group. In another study, it was reported that the incidence of common vertebral deformities decreased when $P$. acidilactici was used in trout (Aubin et al., 2005). Consequently, It was determined that vertebral malformations could be prevented by the addition of probiotic in the first stages of larval development. But, the interaction between probiotic microorganisms, especially lactic acid bacteria and bone conformation has not been clarified, it probably has indirect effect and may be associated with the inhibition of pathogenic bacteria (Villamil et al., 2010). In addition, probiotics may stimulate the immune system and reduce inflammation in fish larvae, local inflammation can affect the integrity of the spine and in this case, it can causes a risk of deformation (Gil-Martens, 2010).

In this research, it was observed that L. rhamnosus ATCC 53103 strain, which was added to Artemia culture or rearing water, did not increase weight gain in sea bass larvae. Nikoskelainen et al., (2001), reported similar results with the use of L. rhamnosus as probiotics in rainbow trouts. The studies carried out regarding the use of Leuconostoc mesenteroides and L. plantarum (Vendrell et al., 2008) in rainbow trout and the use of Lactobacillus lactis (Harzevili et al., 1998) in rotifer cultures also revealed that probiotic bacteria supplements did not have a significant effect on growth performance. Unlike these studies, It has been reported that the body weight of fish is increased in some studies where lactic acid bacteria are used (Carnevali et al., 2006; Lin et al., 2017; Nguyen et al., 2017; Goda et al., 2018). The differences in the results obtained in these studies may be due to fish species used, the concentration of bacteria and the mode of administration.

As a result, the addition of probiotic bacteria to Artemia cultures used as live feeds in larvae was found to be more effective. The use of $L$. rhamnosus ATCC 53103 strain as a probiotic increased survival rate, decreased deformation rate and significantly inhibited Vibrio spp. the potential pathogenic agent for sea bass.

\section{ACKNOWLEDGEMENTS}

This study was supported by TUBITAK ((Project No: TOVAG 104-O-496). We thank to HATKO Sea Products Inc. Products Inc., (Ören, Muğla, TURKEY).

\section{REFERENCES}

Arıg, N., Suzer, C., Gökvardar, A., Başaran, F., Çoban, D., Yıldırım, Ş., Kamacı, H.O., Fırat, HK. \& Saka, Ş. (2013). Effects of probiotic (Bacillus sp.) supplementation during larval development of Gilthead sea bream (Sparus aurata, L.). Turkish Journal of Fisheries and Aquatic Sciences, 13(3), 407-414. DOI: 10.4194/1303-2712-v13_3_03.

Aubin, J., Gatesoupe, F.J., Labbé, L. \& Lebrun, L. (2005). Trial of probiotics to prevent the vertebral column compression syndrome in rainbow trout (Oncorhynchus mykiss, Walbaum). Aquaculture Research, 36(8), 758-767.

Byun, J.W., Park, S. \& Benno, Y. (1997). Probiotic effect of Lactobacillus sp. DS-12 in flounder (Paralichthys olivaceus). Journal of General and Applied Microbiology, 43, 305-308.

Carnevali, O., de Vivo, L., Sulpizio, R., Gioacchini, G., Olivotto, I., Silvi, S. \& Cresci, A. (2006). Growth improvement by probiotic in European sea bass juveniles (Dicentrarchus labrax, L.), with particular attention to IGF-1, myostatin and cortisol gene expression. Aquaculture, 258(1-4), 430-438.

Crespel, A., Zambonino-Infante, J.L., Mazurais, D., Koumoundouros, G., Fragkoulis, S., Quazuguel, P., Huelvan, C., Madec, L., Servili, A. \& Claireaux, G. (2017). The development of contemporary European sea bass larvae (Dicentrarchus labrax) is not affected by projected ocean acidification scenarios. Marine Biology, 164(7), 155. DOI: 10.1007/s00227-017-3178-x. 
Çelik, E.Ş., Ergün, S., \& Yılmaz, S. (2019). Bacillus subtilis ve Lactobacillus plantarum probiyotik bakterilerinin bazı balık patojenleri üzerine in vitro antagonistik etkisi. Journal of Anatolian Environmental and Animal Sciences, 4(2), 278-284. DOI: 10.35229/jaes.592933.

Didinen, B.I., Koca, B., Metin, S., Diler, O., Erol, K.G., Dulluc, A., Koca, H.U., Yiğit, N.O., Ozkok, R. \& Kucukkara, R. (2016). Effect of lactic acid bacteria and the potential probiotic Hafnia alvei on growth and survival rates of narrow clawed crayfish (Astacus leptodactylus Esch., 1823) stage II juveniles. Iranian Journal of Fisheries Sciences, 15(4), 1307-1317.

Franke, A., Roth, O., De Schryver, P., Bayer, T., GarciaGonzalez, L., Künzel, S. \& Clemmesen, C. (2017). Poly- $\beta$-hydroxybutyrate administration during early life: effects on performance, immunity and microbial community of European sea bass yolk-sac larvae. Scientific Reports, 7(1), 15022. DOI: 10.1038/s41598-017-14785-z.

Gatesoupe, F.J. (1991). The effect of three strains of lactic bacteria on the production rate of rotifers, Brachionus plicatilis, and their dietary value for larval turbot, Scophthalmus maximus. Aquaculture, 96(3-4), 335-342.

Gil-Martens, L. (2010). Inflammation as a potential risk factor for spinal deformities in farmed Atlantic salmon (Salmo salar L.). Journal of Applied Ichthyology, 26(2), 350-354.

Gobi, N., Vaseeharan, B., Chen, J.C., Rekha, R., Vijayakumar, S., Anjugam, M. \& Iswarya, A. (2018). Dietary supplementation of probiotic Bacillus licheniformis Dahb1 improves growth performance, mucus and serum immune parameters, antioxidant enzyme activity as well as resistance against Aeromonas hydrophila in tilapia Oreochromis mossambicus. Fish \& Shellfish Immunology, 74, 501-508. DOI: 10.1016/j.fsi.2017.12.066.

Goda, A.M., Omar, E.A., Srour, T.M., Kotiet, A.M., ElHaroun, E. \& Davies, S.J. (2018). Effect of diets supplemented with feed additives on growth, feed utilization, survival, body composition and intestinal bacterial load of early weaning European sea bass, Dicentrarchus labrax post-larvae. Aquaculture International, 26(1), 169-183. DOI: 10.1007/s10499-017-0200-8d.

Grisez, L., Reyniers, J., Verdonck, L., Swings, J., \& Ollevier, F. (1997). Dominant intestinal microflora of sea bream and sea bass larvae, from two hatcheries, during larval development. Aquaculture, 155(1-4), 387-399.

Gumus, E., Aydin, B., \& Kanyilmaz, M. (2016). Growth and feed utilization of goldfish (Carassius auratus) fed graded levels of brewers yeast (Saccharomyces cerevisiae). Iranian Journal of Fisheries Sciences, 15(3), 1124-1133. DOI: 10.22092/IJFS.2018.114596.

Hameed, A.S. \& Balasubramanian, G. (2000). Antibiotic resistance in bacteria isolated from Artemia nauplii and efficacy of formaldehyde to control bacterial load. Aquaculture, 183(3-4), 195-205.

Hamza, A., Fdhila, K., Zouiten, D. \& Masmoudi, A.S. (2016). Virgibacillus proomii and Bacillus mojavensis as probiotics in sea bass (Dicentrarchus labrax) larvae: effects on growth performance and digestive enzyme activities. Fish Physiology and Biochemistry, 42(2), 495-507. DOI: 10.1007/s10695-015-0154-6.

Harrigan, W.F (1998). Laboratory Methods in Food Microbiology. 3rd ed. San Diego, CA, USA: Academic Press.

Harzevili, A.R., Duffel, H.V., Dhert, P., Swings, J. \& Sargeloos, P. (1998). Use of potential probiotic Lactococcus lactis AR21 strain for the enhancement of growth in the rotifer Brachionus plicatilis. Aquaculture Research, 29, 411-417. DOI: 0.1046/j.1365-2109.1998.00217.x.

Jöborn, A., Olsson, J.C., Westerdahl, A., Conway, P.L. \& Kjelleberg, S. (1997). Colonization in the fish intestinal tract and production of inhibitory substances in intestinal mucus and faecal extracts by Carnobacterium sp. strain K1. Journal of Fish Disease, 20, 383-392. DOI: 10.1046/j.13652761.1997.00316.x.

Lamari, F., Castex, M., Larcher, T., Ledevin, M., Mazurais, D., Bakhrouf, A. \& Gatesoupe, F.J. (2013). Comparison of the effects of the dietary addition of two lactic acid bacteria on the development and conformation of sea bass larvae, Dicentrarchus labrax, and the influence on associated microbiota. Aquaculture, 376, 137-145. DOI: 10.1016/j.aquaculture.2012.11.016.

Lin, H.L., Shiu, Y.L., Chiu, C.S., Huang, S.L. \& Liu, C.H. (2017). Screening probiotic candidates for a mixture of probiotics to enhance the growth performance, immunity, and disease resistance of Asian seabass, Lates calcarifer (Bloch), against Aeromonas hydrophila. Fish \& Shellfish Immunology, 60, 474482. DOI: 10.1016/j.fsi.2016.11.026.

Ljubobratovic, U., Kosanovic, D., Vukotic, G., Molnar, Z., Stanisavljevi, N.S., Ristovic, T. \& Jeney, G. (2017). Supplementation of lactobacilli improves growth, regulates microbiota composition and suppresses skeletal anomalies in juvenile pike-perch (Sander lucioperca) reared in recirculating aquaculture system (RAS): a pilot study. Research in Veterinary Science, 115, 451-462. DOI: 10.1016/j.rvsc.2017.07.018.

Marti, E., Huerta, B., Rodríguez-Mozaz, S., Barceló, D., Marcé, R. \& Balcázar, J.L. (2018). Abundance of 
antibiotic resistance genes and bacterial community composition in wild freshwater fish species. Chemosphere, 196, 115-119. DOI: 10.1016/j.chemosphere.2017.12.108.

Muroga, K., Higashi, M. \& Keitoku, H. (1987). The isolation of intestinal microflora of farmed red sea bream (Pagrus major) and black sea bream (Acanthopagrus schlegeli) at larval and juvenile stages. Aquaculture, 65, 79-88.

Nguyen, T.L., Park, C.I. \& Kim, D.H. (2017). Improved growth rate and disease resistance in olive flounder, Paralichthys olivaceus, by probiotic Lactococcus lactis WFLU12 isolated from wild marine fish. Aquaculture, 471, 113-120. DOI: 10.1016/j.aquaculture.2017.01.008.

Nikoskelainen, S., Ouwehand, A.C., Salminen, S. \& Bylund, G. (2001). Protection of rainbow trout (Oncorhynchus mykiss) from furunculosis by Lactobacillus rhamnosus. Aquaculture, 198, 229236.

Nikoskelainen, S., Ouwehand, A.C., Bylund, G., Salminen, S. \& Lilius, E.M. (2003). Immune enhancement in rainbow trout (Oncorhynchus mykiss) by potential probiotic bacteria (Lactobacillus rhamnosus). Fish \& Shellfish Immunology, 15(5), 443-452. DOI: 10.1016/S1050-4648(03)00023-8.

Olsen, A.I., Olsen, Y., Attramadal, M.Y., Chiristie, K., Birkbeck, T.H., Skjermo, J. \& Vadstein, O. (2000). Effect of short term feeding of microalgae on the bacterial flora associated with juvenile Artemia franciscana. Aquaculture, 190, 11-25.

Piccolo, G., Bovera, F., Lombardi, P., Mastellone, V., Nizza, S., Meo, C.D. \& Marono, S. (2015). Effect of Lactobacillus plantarum on growth performance and hematological traits of European sea bass (Dicentrarchus labrax). Aquaculture International, 23(4), 1025-1032. DOI: 10.1007/s10499-014-98618.

Preena, P.G., Dharmaratnam, A., Raj, N.S., Kumar, T.V.A., Raja, S.A. \& Swaminathan, T.R. (2019). Antibiotic susceptibility pattern of bacteria isolated from freshwater ornamental fish, guppy showing bacterial disease. Biologia, 118, 257-275. DOI: 10.2478/s11756-019-00261-8.

Reitan, K.I., Rainuzzo, J.R. \& Olsen, Y. (1993). Nutritional effects of algal addition in first feeding tanks of turbot (S. maximus) larvae. Aquaculture, 118, 257275.

Rollo, A., Sulpizio, R., Nardi, M., Silvi, S., Orpianesi, C., Caggiano, M. \& Carnevali, O. (2006). Live microbial feed supplement in aquaculture for improvement of stress tolerance. Fish Physiology and Biochemistry, 32(2), 167-177. DOI: 10.1007/s10695-006-0009-2.
Silvi, S., Nardi, M., Sulpizio, R., Orpianesi, C., Caggiano, M., Carnevali, O. \& Cresci, A. (2008). Effect of the addition of Lactobacillus delbrueckii subsp. delbrueckii on the gut microbiota composition and contribution to the well-being of European sea bass. Microbiol Ecology in Health and Disease, 20(1), 5359. DOI: 10.1080/08910600701876020.

Sutthi, N., Thaimuangphol, W., Rodmongkoldee, M., Leelapatra, W. \& Panase, P. (2018). Growth performances, survival rate, and biochemical parameters of Nile tilapia (Oreochromis niloticus) reared in water treated with probiotic. Comparative Clinical Pathology, 27(3), 597-603. DOI: 10.1007/s00580-017-2633-x.

Tovar-Ramirez, D., Infante, Z.J., Cahu, C., Gatesoupe, F.J. \& Vazquez-Juarez, R. (2004). Influence of dietary live yeast on European sea bass larval development. Aquaculture, 234, 415-427. DOI: 10.1016/j.aquaculture.2004.01.028

Van Doan, H., Hoseinifar, S.H., Khanongnuch, C., Kanpiengjai, A., Unban, K. \& Srichaiyo, S. (2018). Host-associated probiotics boosted mucosal and serum immunity, disease resistance and growth performance of Nile tilapia (Oreochromis niloticus). Aquaculture, 491, 94-100. DOI: 10.1016/j.aquaculture.2018.03.019.

Vendrell, D., Balcázar, J.L., de Blas, I., Ruiz-Zarzuela, I., Gironés, O. \& Múzquiz, J.L. ( 2008). Protection of rainbow trout from lactococcosis by probiotic bacteria. Comparative Immunology, Microbiology \& Infectious Diseases, 31, 337-345. DOI: 10.1016/j.cimid.2007.04.002.

Villamil, L, Figueras, A., Planas, M. \& Novoa, B. (2010). Pediococcus acidilactici in the culture of turbot larvae: administration pathways. Aquaculture, 307(1-2), 83-88. DOI: 10.1016/j.aquaculture.2010.07.004. 